\title{
Exclusion and Inclusion in the Danish Military
} A Historical Analysis of the Construction and Consequences of a Gendered Organizational Narrative

\author{
Muhr, Sara Louise; Sløk-Andersen, Beate
}

Document Version

Accepted author manuscript

Published in:

Journal of Organizational Change Management

DOI:

10.1108/JOCM-10-2016-0195

Publication date:

2017

License

Unspecified

Citation for published version (APA):

Muhr, S. L., \& Sløk-Andersen, B. (2017). Exclusion and Inclusion in the Danish Military: A Historical Analysis of the Construction and Consequences of a Gendered Organizational Narrative. Journal of Organizational Change Management, 30(3), 367-379. https://doi.org/10.1108/JOCM-10-2016-0195

Link to publication in CBS Research Portal

\section{General rights}

Copyright and moral rights for the publications made accessible in the public portal are retained by the authors and/or other copyright owners and it is a condition of accessing publications that users recognise and abide by the legal requirements associated with these rights.

\section{Take down policy}

If you believe that this document breaches copyright please contact us (research.lib@cbs.dk) providing details, and we will remove access to the work immediately and investigate your claim. 


\section{Exclusion and Inclusion in the Danish Military: A Historical Analysis of the Construction and Consequences of a Gendered Organizational Narrative}

\section{Sara Louise Muhr and Beate Sløk-Andersen}

Journal article (Accepted manuscript)

CITE: Muhr, S. L., \& Sløk-Andersen, B. (2017). Exclusion and Inclusion in the Danish Military: A Historical Analysis of the Construction and Consequences of a Gendered Organizational Narrative. Journal of Organizational Change Management, 30(3), 367-379.

DOI: 10.1108/JOCM-10-2016-0195

This article is (0) Emerald Group Publishing and permission has been granted for this version to appear here: https://research.cbs.dk/da/publications/exclusion-and-inclusion-in-the-danish-military-a-historical-analy. Emerald does not grant permission for this article to be further copied/distributed or hosted elsewhere without the express permission from Emerald Group Publishing Limited.

Uploaded to Research@CBS: December २018 


\title{
Exclusion and inclusion in the Danish military: A historical analysis of the construction and consequences of a gendered organizational narrative
}

\begin{abstract}
Purpose: The purpose of this paper is to examine why and how past stories of women's insufficiency for military work survive and how they come to form a gendered organizational narrative dominant in constructing current opinions on women in the military.
\end{abstract}

Design/methodology/approach: The analysis is based mainly on archival data, but supported by interview material as well as participant observation data. We do this from the assumption that the culturally constructed notion of the ideal soldier is based on a historically constructed professional narrative.

Findings: We show how a historically produced gender narrative - based on (fictional) stories on what women can and can't do - is perceived as true and thereby casts women as less suitable for a military career. Thus, despite the current equal legal rights of men and women in the military, the power of the narrative limits female soldiers' career possibilities.

Originality/value: The paper is unique as it in drawing on archival data is able to trace how an organizational narrative comes to be and due to its ethnographic data how this creates limitations for women's careers. This narrative is stronger and much more powerful than management is aware of. The paper therefore adds crucial knowledge about the ideological influence a historically produced organizational narrative can have on current change initiatives.

Keywords: Diversity change programs, gender narrative, historical analysis, inclusion, exclusion, military

Paper type: Research paper 


\section{Introduction}

Many organizations are today engaged in various diversity programs in the attempt of increasing the percentage of women in their organization, especially at senior level (Muttarak et al., 2013; Oswick and Noon, 2014; Quin et al., 2014). It has been shown that such attempts of changing the gender composition of organizations are highly influenced by the profession within which the organization operates, as professions due to their historical meaning tend to have developed subtle cultural codes for the way individuals are seen as suitable (or non-suitable) for the work performed in a given profession (Ashcraft, 2013; Ashcraft et al., 2012; Butler et al., 2012; Davies, 1996; Sullivan, 2012). As professions tend to be read as masculine (opposite to the feminine connoted semiprofessions that e.g. Hearn (1988) very successfully has shown), these cultural codes are highly gendered, and in this way work as subtle but powerful inclusion or exclusion mechanisms often obstructing the more formal inclusion programs (of e.g. women) aiming at changing the organization (Ashcraft et al., 2012). Therefore, particularly professions culturally read as masculine seem to struggle with including women on equal terms with men.

Here, the military most likely have a sense of professionalism more deeply rooted in masculinity than any other, as they until very recently have excluded (and some places still do exclude) women from taking part of much of the work (Carreiras 2006; Carreiras and Kümmel 2008; Kronsell 2012, Mackenzie 2015, Totland 2009). This has been argued to be one of the main reasons why national military organizations still to a high degree are defined by a masculine ideology that sanctions expressions of femininity (Carreiras 2006; Totland 2009) and (if not formally, then) informally exclude women from parts of the work performed in national defenses all over the world. The Danish military has since the early 2000s focused on gender inclusion in order to increase the number of women in the Danish Armed Forced. However, while the number of women doing military service has increased, the numbers have not changed much at higher levels. Several explanations have been given as to why this is so, e.g. that women due to their assumed 'natural' nurturing instincts are unable to take another person's life. Another argument has been that women due to weaker bodies and psyches are 
not capable of performing the exhausting job as a soldier. And yet another argument is that women are just not interested in being part of this profession that it is 'a man's thing'. However, these arguments are very questionable in the light of the high number of women voluntarily signing up for military service in Denmark; a service they could easily avoid without any questions asked. Equally relevant, studies on the actual performance of military work carried out by women and men in the military has shown no clear evidence that women who take part in military work should be less competent than their male colleagues (Mackenzie, 2015; Carreiras and Kümmel, 2008). ${ }^{1}$ Nevertheless, there are plenty of stories being told about why so few women are part of the military profession, yet few feasible explanations as to why this is the case.

We are in this paper interested in why such stories survive and how they become so dominant in constructing the opinion on women in the military. We do this from the assumption that the culturally constructed notion of the ideal soldier is based on a historically constructed professional gender narrative that works as a frame of reference for meaning construction about women in the Danish Armed Forces. In this way we lean on Hawkins and Saleem (2012, pp. 208) as they state that narratives are "the cognitive framework that guides an individual in making sense of experiences" often in subconscious and subtle ways through cultural codes. We will in this paper analyze how a historically produced gendered narrative on what women can and can't do casts women as less suitable for a military career despite the current equal legal rights of men and women in the military. Our argument, then is, that this narrative is stronger and much more powerful than management is aware of and before this is addressed and some of the myths killed, the military will have difficulties experiencing change from its inclusion programs. Addressing this aim, the paper therefore asks the following question: How does a gendered organizational narrative constructed through a history of exclusion create barriers for current inclusion of women in the Armed Forces?

\footnotetext{
1 This issue is closely tied to questions of how competencies are valued and measured in the military - an issue we shall return to at the end of this paper.
} 


\section{Studying diversity change programs}

While several studies show that diversity in organizations pays off economically (e.g. Herring, 2009; Lyngsie and Foss, 2016), it is also a well-known fact that organizations do not optimize the diversity of the human resources at their disposal. This is evident as, for example, women and ethnic minorities remain underrepresented in management positions, boards of directors as well as certain occupations (Chamorro-Premuzic, 2013; Zanoni and Janssens, 2015). The discrepancy between potential gains and actual practices has led research on diversity to focus on developing methods for increasing the number of minorities in leadership positions. Hence, tools and initiatives like sensitivity training, networks, mentoring, and 'minority only' programs have been developed and implemented (e.g. Clarke, 2011; Kossek et al., 2006).

Critical scholars have recently shown that traditional diversity management practices as well as studies of these are guided by functionalistic, generalized, decontextualized and de-politicized HRM practices (Janssens and Zanoni, 2014; Oswick and Noon, 2014), which do not capture the complexity of the diversity issues that organizations have to deal with. This criticism has successfully exposed problematic underlying norms and ideologies, which form specific gendered, raced, classed and sexed perceptions of (and expectations to) people (e.g. Ashcraft, 2013; Muhr and Salem, 2013; Muhr and Sullivan, 2013). Such perceptions obstruct the successful implementation of the very diversity practices that were meant to overcome them (Klarsfeld et al., 2012; Muhr, 2011).

The majority of these recent studies and critiques of diversity management and diversity research are theoretically grounded in the so-called 'linguistic turn' (Alvesson and Kärreman, 2000), emphasizing how diversity practices are embedded in and influenced by discourses of difference (e.g. Christiansen and Just, 2012; Zanoni and Jansens, 2004). Within the literature on gender 'after' the linguistic turn, the main argument has been that power, history and organizational culture discursively constructs gendered norms and ideologies (see Ahonen et al., 2014; Tracy and Rivera, 2010), which limits gender performances to that which is socially accepted (Cheney and Ashcraft, 2007; Ford, 2006; Muhr and Sullivan, 2013) or in the case of professions perceived to be within the boundaries of a 
given profession (Ashcraft, 2013). Discursive constructions of gender can be seen in both everyday language of organization members, in the way organization members tell stories about themselves and others as well as the way organizations represent gender initiatives through more official channels. All of these linguistic sources (and more) make up an organisation's narrative, which defines who and what they are and what they stand for. Taking a discursive approach to studying gender therefore means going away from asking questions such as 'how should diversity be managed' and instead ask the question 'how is diversity constructed and how does such a construction influence practice'? (see also Zanoni and Janssens, 2004). By identifying an organisation's gender narrative, we can thereby gain important knowledge about how diversity is constructed and practiced in an organization.

\section{The role of organizational narratives}

Flory and Iglesias (2010) already in the 2010 JOCM special issue on rhetoric and narratives in management research asked the crucial question: What impact do stories have? In answering this, they point to the power narratives have as "the reflective product of looking back and making sense of stories constructed to make sense of life" (Flory and Iglesias, 2010, pp. 116-117). Narrative is therefore “a way of understanding one's own and others' actions, of organizing events and objects into a meaningful whole, and of connecting and seeing the consequences of actions and events over time" (Chase, 2005, pp. 656, see also Parada and Villadas, 2010). Stories can therefore be used by individuals "to make sense of their lived experiences and organize these experiences within their narratives" (Hawkins and Saleem, 2012, pp. 206). Through this process, narratives come to convey an experience of objectivity (Gosseff, 2014), and are therefore rarely questioned, but rather taken for granted truths about an organization (Essers, 2012). Actions, therefore, are difficult to interpret if they are not viewed in the light of grander organizational narratives (Hawkins and Saleem, 2012) and the materialization of these as practices and symbols in the organization.

If we, by following this, define stories as the use of words to tell a tale and narratives as the collective cognitive framework (or ideology), which stories draw 
their meaning from (Hawkins and Saleem, 2012), then it is the gendered narratives formed through military history, which give meaning to the stories told today. Dawson et al. (2014) make such connection to time, as they "bring to the fore the often hidden notion of time in utilizing concepts from a range of literatures in examining temporality, stories and sensemaking in a context in which future possibilities are made sense of in the present through restorying experiences and events from the past". However, where Dawson et al. develop their thinking in relation to improving change experiences and increasing commitment to change, we take a step back and focus on how historically shaped narratives form present story telling in ways that are detrimental for change, in our case changing the perception of women in the organization. So to add to Hawkins and Saleem's (2012) debate about how stories obtain their narrative fragments, which make them so powerful and influential, our answer is formed around the meaning generated through historical anecdotes that come to be seen as true. Here Essers' (2012) insightful analysis of how “illusions are disseminated through narrative, serve as the backbone of everyday practices in organizations and society" is particularly useful. Thus identifying an organization's historically produced gender narrative can therefore assist us in understanding how gender is discursively constructed and how it influences how work is perceived and performed in a given organization, in this case the Danish Armed Forces.

\section{Methodology}

As Essers (2012, pp. 349) points out, management research is troubled by a "false choice between narrative 'meaning' and scientific 'truth'”. Essers instead points to the fact that narratives are carriers of ideological fantasies, which then shape the way we perceive so-called 'truth' and 'facts' and use them to make sense of experiences. Narratives are therefore crucial for understanding how perceptions about the 'ideal worker' in a given profession are constructed not only from objective facts, but always intertwined with a 'narrative truth' as Bruner (1986) among others referred to.

Narratives are constructed both from texts, material objects, images, actions and stories (Hawkins and Saleem, 2012). This means that the analysis, in which we 
identify the historical construction of the current gender narrative, should draw on historical texts, pictures, objects as well as collected stories about the past. We therefore make use of archival and document analysis combined with interviews and observations to understand how the gender narrative in the Danish Armed Forces is formed historically and influence opinions about gender and the ideal soldier today.

\section{Archival / document analysis}

As a way to map the history of women in the Danish military, one of the authors spent four months examining historical documents. Looking at how women gained access to actual military positions in the second half of the $20^{\text {th }}$ century, the author traced women's military careers back to the outburst of The Second World War. Thus, the scope of the historical analysis starts in 1939 and up until equal rights for men and women in the Danish Armed Forces were established in 1992, with still more written material to be found for each decade. However, as only few historical accounts about women's presence in the military exists, 'pieces of the puzzle' were found in e.g. propositions for new legislation, transcripts of parliament debates, yearbooks, status reports, autobiographies, action plans, strategy papers, HR policy papers as well as evaluation reports. Thus, the data for the historical analysis is based on a carefully identified cacophony of voices from former commanders, government officials at the Ministry of Defense, politicians, the national Equality Council, researchers, etc.

\section{Interview and observation data}

The interview and observation data comes from three sections of data collection in the Danish Armed Forces. Both authors were involved in separate parts of this, and both therefore have an in depth empirical understanding of the organization. First, 22 interviews were conducted in the Danish Defence Personnel Organization and the Ministry of Defence in 2015. 2/3 of these interviews have been conducted with military personnel and $1 / 3$ with civilian personnel. Half of the interviews were with men and half with women. Second, as part of the historical analysis, 
qualitative interviews with six of the first women to achieve rank of officer in Denmark were carried out in the fall of 2013. These women were identified via graduation pictures from the military academies or by researchers at the Royal Danish Defence College who have met or heard of some of these women. Only women who were still part of the Danish military were interviewed, which surely has an effect on the stories that have been gathered - compared to the stories women who have chosen to leave the organization might have told. Third, an additional 36 qualitative interviews with recruits and commanders were carried out at the end of a participatory fieldwork in 2016 in which one of the authors joined a group of conscripted soldiers through their four month basic training. This work resulted in loads of rich observations, embodied experiences and 45 hours of interview recordings, which is also included in this analysis. Finally, both authors have visited a number of military barracks and had meetings with leaders at different levels within the military; experiences that have contributed to our knowledge and understanding of the organization.

Doing interviews seems essential when studying the construction of narratives in an organization. The large number of interviews behind this analysis has provided us with numerous stories about the military profession as well as articulations that can disclose normativity around gender (Søndergaard, 2000). Concurrently, observations have enabled insights that informants may not have wished to share or did not consider to be of interest to the researcher (Spradley, 1980). Including observations has thus entailed insight into how gender differences and gendered possibilities are produced via both articulations and actions.

\section{Historical analysis of the Danish military: exclusion, inclusion and the construction of the gender narrative}

The Danish Armed Forces is somewhat standardized in its organization as it consists of an army, a navy and an air force as well as a couple of additional special operation units. The military employs around 20,000 people of which $3 / 4$ fill military positions while the last $1 / 4$ are civilians. In addition to this group of employees comes another 4,200 conscripted soldiers each year of which most serve in the army. 
As one of the few countries in NATO, Denmark's Armed Forces are still based on a foundation of conscripted soldiers. Despite compulsory military service having 'gone out of style' across most of the Western world (Carreiras, 2006), Denmark still upholds the duty of (male) citizens to serve their country when they have reached the age of $18 .^{2}$ The conscription period has, however, been cut down to consist of only four months basic training during which recruits are taught the basics of combat as well as emergency management and first-aid. Subsequently, soldiers can proceed onto more advanced educational programs and jobs in the military, e.g. the Army's Reactional Unit Program, which trains recruits to become professional soldiers who can be deployed in international missions.

Women can serve alongside male recruits on so-called 'conscription-like conditions' by volunteering for military service - a possibility that was introduced in 1998. Today, women make up a greater percentage of the conscripted soldiers in the Danish military than ever before. From having made up a mere 2.6 percent in 2004, they made up 17.7 percent in 2016. This increase is no doubt related to a contemporary political focus on this topic, which has effectuated itself in inclusion programs and efforts to recruit more women at the entry level. However, the increase in women joining the basic program is not reflected higher up in the organization: The percentage of women continuing onto a career within the military as well as the overall percentage of women in military positions (the conscription period not being considered a 'position') has shown little growth within the last decade. ${ }^{3}$ In the following section, we will turn back time and explore the development of the entry of women in the Danish military as a way to better understand the current gender narrative and how it creates challenges to gender integration and inclusion.

Moments of inclusion and exclusion of women in the Danish military

\footnotetext{
2 However, the entire cohort of 18 year olds is not called upon for military service. Currently, only 4,200 conscripts are enlisted each year - out of a total of 69,800 men and women aged 18 .

${ }^{3}$ Over the last six years, the percentage of women in military positions has moved both up and down, overall going from 6.2 in 2010 to 6.8 percent in 2016. A few years earlier, in 2007, the percentage of women was 5.0 percent.
} 
Little record has been kept of the presence of women in the Danish military prior to the 1980's. Women have nonetheless contributed to the national defense and military work in Denmark long before, albeit this contribution has arguably been silenced - by men as well as women - to uphold a perception of violence as something manly and peace as something womanly (Larsen, 1994). Larsen has given specific examples of Danish women through history who have taken part in combat and wars. However, most of these women were involved in war and combat via supporting roles such as accompanying nurses or wives following the military unit into battle. Here, we will engage with the question of how women through the $20^{\text {th }}$ century gained access to the military profession in Denmark how women through mechanisms of inclusion and exclusion gradually have gotten closer to being perceived as suitable members of the military profession.

As mentioned, women's military function started out being primarily that of support to combatants, something that positioned them outside the military profession as such, e.g. symbolized by their lack of uniforms. In the time just around World War II, a number of volunteer corps were created in Denmark, most of them made up solely by women. The original aim of these corps was to help evacuate citizens during the war but the women were also taught to perform other tasks such as cooking for large groups of people, nursing and office work. This concept of volunteer women's corps was widespread in the Nordic countries (Sundevall, 2011; Jensen and Frøling, 2006). By 1952 all branches of the military had a female volunteer corps; the army, the navy and the air force all had women in uniform assisting them in their work by taking part in combat support tasks such as surveillance, technical services and signaling. Thus, these corps opened the door to the military profession for women albeit this first step towards inclusion being conditional to an international crisis. However, as we will argue later on, this supporting role would turn out to inhibit the full inclusion of women in the military organization, as stories of these pioneer women might be positive and in favor of women serving, but at the same time also constructing cultural codes for women in the military around their initial tasks focused on nurture, care and support rather than combat and protection. 
It was nevertheless their previous presence in the military - that the women were already there, in uniforms, doing military work - that made it possible for women to be hired on military contracts in 1962. With the adoption of this change, women would still be affiliated to the women's corps but would have a better juridical foundation since they would now actually be employed. This way, they were included in the way that they could now get a contract with the Danish Armed Forces, yet they were simultaneously marginalized by being excluded from the 'real' military through the affiliation to separate women's sections. This new development had an additional two massive exceptions that underpinned the difference between men and women in the military: The women would (still) not be paid for the work they did and they were not allowed to take part in combat. Maybe not surprising, these conditions did not attract a lot of women.

A key advancement in the rights of women regarding military careers happened in 1971 where the entry levels in the military (as privates and sergeants) were opened up to women, thus making them actual members of the military profession. While women would now be acknowledged for their work by being paid, they could still not be employed in positions "that primarily included a chance of direct participation in combat" (Haslund-Christensen, 1988, p. 84). Shortly after, women gained access to the military academies of each of the military's three branches where soldiers had the possibility to advance to officers - a crucial step for the potential advancement to even higher ranks in the military (Sløk-Andersen, 2014). However, few women (or men) seemed to know of the possibility to become an officer and even fewer women entered the academies in the 1970's (and the 1980's) - partly because of stories about the academies being male-only territory lived on. For instance, one informant told how her own father, a military man himself, convinced her that she as a woman was not eligible to apply - an incorrect fact that was later corrected by one of her friends at which point she applied and was accepted.

According to the few women who entered the military academies at this time, the military did not appear to have been prepared to grant women access. Rather, a lack of facilities and equipment for the women as well as a general confusion over what 'to do' with these women suddenly being accepted seemed to define the 
experiences of the first women at the military academies, thus indicating that this decision to include women in the higher ranks might very well have been made outside the organization (Sløk-Andersen 2014). The role as high-ranked commanders did not fit with the narrative of women as barely-suitable soldiers.

This somewhat hesitant inclusion process during the 1970's could be argued to have been driven by the rise of gender equality legislation in Denmark. Political intentions regarding equality were consolidated in the Law on Equal Pay in 1976 and the Law on Equal Treatment in 1978 as well the creation of a national Equality Council in 1975. Already within its first years, the council received complaints from women who were denied access to various educational programs within the military. And the Danish military did in fact seem to actively try to exclude women from gaining full membership of the profession: At the adoption of the Law on Equal Treatment in 1978 which among other things determined that women and men should be treated as equals in questions of employment, the military instantly appealed for an exception from the law. The reason for this appeal was that this would be the only way to uphold the exclusion of women from combat - which was still in function despite the advancement of women who at this point were entering the military academies. Based on arguments about the uncertainty of how women would react to the pressure of combat, the military was given a total of 10 years of redemption from the Law of Equal Treatment. However, this came with a requirement to conduct trials with women in combat roles during the redemption period. In this period, women continued to be what we might call 'excluded insiders', being included by national legislation yet being attempted excluded from combat by the very profession they believed to be part of. The evaluation and recommendations following these trials were highly debated and some were even rewritten on orders from the Ministry of Defense (Bork and Nørby 2010, Sløk-Andersen 2014). The final outcome was a positive evaluation of women's capabilities to fulfil the role of combat soldiers due to which the exception from the Law on Equal Treatment could no longer stand. Thus, the combat exclusion was eroded in 1988.

In principle, women now had full access to all military positions but one: Due to stories about how the extreme G-force during flying could potentially damage 
women's reproductive organs, women were still not allowed to be fighter pilots before evidence on this was gathered and examined. Yet, no such study was carried out regarding the reproductive health of the male pilots. Thus, the narrative about how women and their bodies were an ill fit with military tasks lived on and showed itself powerful despite a greater formal inclusion of women. In the end, there was not sufficient evidence that flying would harm women's bodies and the ban was therefore terminated in 1992, hereby eliminating the last formal restriction on women's participation in the military.

Another defining point in the formal equality between men and women in the Danish Armed Forces happened in 1998 where women were given the possibility to serve alongside conscripted male soldiers under 'conscription-like conditions'. This meant that men and women were now gathered in the same military education program, giving them the exact same competencies via a common basic training at the military barracks. Since 2006, all women have additionally been invited to the information and assessment events obligatory for all men the year they turn 18, and as of 2016, most conscripted soldiers stay in co-ed housing as a way to downplay existing gender barriers (Ellingsen et al. 2016), and potentially increase the number of women who continue onto a military career. Furthermore, gender equality was included as a principle in the HR policy for the Danish Armed Forces in 2003: another indication of an organization that tries to challenge gender narratives casting women as unwanted and unsuitable. Unfortunately, a survey on gender-based misconduct - also from 2003 - showed that one in three women had experienced this type of behavior from colleagues in the military (Øhrstrøm et al., 2003). Women were via oral and physical actions getting a lot of negative attention due to their non-normative gender. That this survey and the addition of gender equality to the HR policy appeared the same year shows the coexistence of inclusion and exclusion processes. Today, the only formal genderbased difference that still stands is that conscription only applies to men - a crucial difference when trying to challenge gender dynamics, we would argue, as this continues to frame men as more suitable for the job as a soldier than women.

\section{Discussion: The power of the narrative today}


While the assistance women offered the Danish military through their volunteer work during The Second World War to a large degree was pivotal to their later access to 'real' military positions, their participation in these supporting units casted women as supporters. This organizational narrative of women as supporters rather than combatants has lived on and is key when trying to understand the gender dynamics and integration issues of contemporary military organizations. We argue that it cannot simply be disregarded as a historical account since several of the so-called 'truths' produced by this narrative has influenced - and still influence - the careers of female officers. This narrative is for instance found in the praising of women's contributions to CIMIC (civilmilitary) activities, which are centered on dialogue and intercultural competencies rather than aggression and physical strength. An appraisal mostly emphasized by (male) officers in the military ironically as a way to complement their female colleagues. However, the reiteration of this 'compliment' is concurrently writing women out of the narrative about combat on which the military profession could be argued to be based, displacing women to a supportive role as communicators rather than fighters. This displacement is strengthened by a number of accounts during our fieldwork where young women have been told that they were not able to apply to the Danish special operation units due to their gender. This limitation was formally eliminated in 1988, yet when a female recruit during a career event at a military barrack in the spring of 2016 asked about women's possibilities to apply for one of the special operation units, she - and the rest of the 150 recruits in the auditorium - were told by a recruitment officer that 'we are looking into opening the unit to women'. This type of (incorrect) reply may explain why no woman has ever served in these units. Concurrently, it underpins that women are still not (despite formal rules) perceived as full-blown members of the profession, and adds to the gender narrative that women are per definition never 'elite' soldiers. Equally, the historical data presented in this article has for one of the authors given rise to a number of debates as many current and former employees in the military argue that duty in e.g. submarines and the special operation units were not opened up to women before the mid-1990's or even later. Despite the fact that there is no evidence or juridical basis for these claims just as the stories about current limitations regarding women's access to special 
operation units go against formal policy and legislation - these still to a large degree successfully limit women from parts of the profession because they are presented and understood as 'truths' within the organization.

To support the gender narrative of women as more suitable for support functions, physical strength still functions as one of the primary bases for exclusive practices in the military, drawing on narratives about women being too weak to be full members of the military profession (Maninger, 2008; Creveld, 2002). During the participatory fieldwork, some sergeants have in training sessions repeated a mantra about physical training not being about getting 'big guns' but rather a strong core to enhance balance and help avoid injuries. Nonetheless, photos of Arnold Schwarzenegger at the peak of his bodybuilder career still appeared during formal lectures, indicating a quite different organizational, physical ideal. Despite women possibly even having an advantage if physical strength was measured in accordance to core strength, they still suffer under a narrative about weakness. One reason is that while the official policy for physical training may be focused on core strength, norms and stories about strength in the military still cling to the well-known push-up - in which it could be argued that women are disadvantaged due to a much smaller muscle mass in the upper body. Maybe due to an acknowledgement of this, one sergeant would - during the observed training of recruits - always yell 'only women are allowed to do push-ups on their knees'. Unfortunately, this type of gender specific 'consideration' entails an indication that only women could be challenged by doing the 15-20 push-ups while no men could possibly have difficulties doing them on their toes. In reality, when looking around at the 53 recruits, just as many men as women were on their knees - or giving up all together. Thus, the story of push-ups being defining for strength ends up being a contemporary exclusion mechanism, labelling women as 'not strong enough' for the military, despite formal attempts to establish more 'gender neutral' ways of assessing and building physical strength.

As the gender narrative targets or addresses the core capability of what it means to be a successful soldier, the narrative also reinforces the current norm that women are non-suitable for the role as commanders; few women have reached higher levels of leadership within the Danish Armed Forces. Obviously, with few 
women entering the military academies in the 1970's and 1980's, it would be odd to have large numbers of women in high-ranked positions today as these positions are limited to those who have achieved the title as officer. However, even at the basic level, a female recruit made second-in-command in her squad, explained during an interview how hard it was to carry out this role "because they [her male colleagues] might think it sucks being bossed around by a 20 year old girl" which she experiences by not always being "taken seriously" and having to "prove [herself] more". Supporting her suspicion that the female gender has an effect on her possibility to lead, a male colleague said in his interview:

I respect her. I think she's a good second-in-command and I understand why she is second-in-command rather than me and all that, whereas many might think 'Oh, but she's only second-in-command because she is a girl [...] It's not like that. I can sense that she is fighting for it. She's passionate about it. She wants it. And that's why I just have respect [for her] instead. And I think it's too bad that she isn't getting the credit that... sometimes should be given.

Affecting women's access to leadership is not only cultural codes casting them as non-combatant but also things as elementary as the (deep, masculine) tone of voice needed to yell commands to an entire platoon as well as women's uniforms with too little room for advanced distinctions on the shoulders - hereby challenging women's access to leadership in subtle ways.

\section{Conclusion}

With this paper, we have aimed at showing how the history of inclusion and exclusion within the Danish Armed Forces has created a very specific gender narrative around support, nurture and weakness, which serves as a barrier for women's careers in the military today. Overall we found that women are (still) constructed - and referred to in stories - as weaker, less powerful and less suitable for being soldiers compared to men, who fit the masculine ideal within the military profession. Women's inferiority is inscribed narratively into the military organization in diverse ways; as stories about limitations in women's 
access to various units, uniforms that do not have room for distinctions, the recurrent push-ups and lack of 'credit' for women in leadership. Many of these stories, however, are not based on facts, but on untrue myths and false information. Still, they seem to be stronger and more powerful in constructing the present day opinion about female soldiers and their career possibilities, thereby obstructing the change initiatives based on actual facts and managerial support for women.

The main point we have attempted to convey is that when an organization or a profession has a strong gendered history (which many professions, not only the military, do), it is not possible to deal with contemporary inclusion processes without addressing stories of exclusion (no matter whether they are true or not) and the power these hold through forming organizational narratives about which - and how - certain bodies belong in the profession (in this case military). Thus, current opportunities for women when it comes to being hired, choosing their field of specialization, being promoted, being in command, or in more general terms being included in all aspects of their everyday life in the military, are shaped by a historically produced organizational narrative. Such a narrative is particularly powerful exactly because it is based on myths and stories, something that is foundational for the organizational culture and the ideological constructions around it (Essers, 2012). When current gender policies and initiatives aiming at increasing the percentage of women are less successful than what was expected, we need to acknowledge the role of historically constructed professional gender narratives ideologically shaping normativity within the specific profession today.

So, although Gabriel (2008) warned us about the deceptive features of stories when constructed by spin-doctors and image brokers, we show how this deception does not have to happen through the deliberate construction of misleading narratives, but can also happen through the historical construction of the narrative upon which present day meaning is generated. As Žižek (e.g. 1989) has reminded us repeatedly, ideology works better when it is not deliberate or acknowledged - and as we add here, when it is worked into an organizational narrative. 
Thus, the contribution of this paper is to show the function of historically constructed narratives for organizational change and thereby how important knowledge about a profession's historically developed narrative is to understand current attempts of organizational change. So, when an organization, like the Danish Armed Forces works actively and seriously towards changing the gender composition of the organization - e.g. by setting strategic goals and launching initiatives to attract more women - history and the historically constructed gender narrative is of crucial importance. One cannot look at inclusion without taking historical exclusion into consideration. The way women historically have been excluded from the military profession works as a powerful organizational narrative, which influences any attempt of inclusion.

\section{References}

Ahonen, P., Tienari, J., Meriläinen, S. and Pullen, A. (2014), "Hidden contexts and invisible power relations: A Foucauldian reading of diversity research". Human Relations, Vol. 67 No. 3, pp. 263-286.

Alvesson, M. and Kärreman, D. (2000), "Taking the linguistic turn in organizational research: Challenges, responses, consequences”, Journal of Applied Behavioral Science, June 2000 Vol. 36 No. 2, pp. 136-158.

Ashcraft, K.L. (2013), “The glass slipper: "Incorporating” occupational identity in management studies", Academy of Management Review, Vol. 38 No. 1, pp. 6-31.

Ashcraft, K.L., Muhr, S.L., Rennstam, J. and Sullivan, K. (2012), “Professionalization as a branding activity: Occupational Identity and the dialectic of inclusivityexclusivity", Gender, Work \& Organization, Vol. 19 No. 5, pp. 467-488.

Bruner, J. (1986), Actual Minds, Possible Worlds, Cambridge, MA, Harvard University Press.

Butler, N., Chillas, S. and Muhr, S.L. (2012), "Professions at the margin”, Ephemera: Theory and Politics in Organization, Vol. 12 No. 3, pp. 259-272.

Carreiras, H. (2006), Gender and the Military. Women in the Armed Forces of Western Democracies, Routledge. 
Carreiras, H. and Kümmel, G. (2008), "Off Limits: The Cults of the Body and Social Homogeneity as Discoursive Weapons Targeting Gender Integration in the Military", in H. Carreiras and G. Kümmel (Eds.), Women in the Military and Armed Conflicts. VS Verlag für Sozialwissenschaften, pp. 29-47.

Chamorro-Premuzic, (2013), "Why do so many incompetent men become leaders?", Harvard Business Review, August.

Chase, S. (2005), "Narrative inquiry: Multiple lenses, approaches, voices", in

Cheney, G. and Ashcraft, K.L. (2007) Considering 'the professional' in communication studies: implications for theory and research within and beyond the boundaries of organizational communication. Communication Theory, 17,2, $146-75$.

Christiansen, T. and Just, S.N. (2012), "Regularities of diversity discourse: Address, categorization and invitation", Journal of Management and Organization, Vol. 18 No. 3, pp. 398-411.

Clarke, M. (2011), “Advancing women's careers through leadership development programs", Employee Relations, Vol. 33 No. 5, pp. 498-515.

Davies, C. (1996), 'The sociology of the professions and the profession of gender", Sociology, Vol. 30 No. 4, pp. 661-678.

Denzin, N. and Lincoln, Y. (Eds.), The SAGE Handbook of Qualitative Research, Sage, Thousand Oaks, CA, pp. 651-679.

Creveld, M.V. (2002), Men, Women \& War: Do Women Belong in the Front Line?

Dawson, P., Sykes, C., McLean, P., Zanko, M. (2014), "Stories affording new pathways: Bridging the divide between aged and disability care", Journal of Organizational Change Management, Vol. 27 No. 5, pp. 819-838.

Ellingsen, D.; Lilleaas U.-B. \& Kimmel, M. (2016): "Something is working - but why? Mixed rooms in the Norwegian Army", NORA - Nordic Journal of Feminist and Gender Research, 24:3, pp. 151-164.

Essers, J. (2012), "Re-writing the organization: The ideological deadlock of narrative methodology", Journal of Organizational Change Management, Vol. 25 No 2, pp. 332-351. 
Flory, M. and Iglesias, O. (2010), "Once upon a time”, Journal of Organizational Change Management, Vol. 23 No. 2, pp. 113-119.

Ford, J. (2006), "Discourses of leadership: Gender, identity and contradiction in a UK public sector organization", Leadership, Vol. 2 No. 1, pp. 77-99.

Gabriel, Y. (2000), Storytelling in Organizations: Facts, Fictions and Fantasies, Oxford University Press, Oxford.

Gabriel, Y. (2008), "Seduced by the text: the desire to be deceived in story, memoir and drama", Tamara Journal, Vol. 7 No. 2, pp. 154-67.

Gelis-Filho, A. (2012), “Organizations as discursive gravitational fields”, Journal of Organizational Change Management, Vol. 25 No. 2, pp. 236-250.

Goosseff, K.A. (2014), "Only narratives can reflect the experience of objectivity: Effective persuasion", Journal of Organizational Change Management, Vol. 27 No. 5, pp. 703-709.

Haslund-Christensen, S. (1988), Landakademiet og Hærens Officerskole 1713-1988, Hærens Officerskole.

Hawkins, M.A. and Seleem, F.Z. (2012), “The omnipresent personal narrative: Story formulation and the interplay among narratives", Journal of Organizational Change Management, Vol. 25 No. 2, pp. 204-219.

Hearn, J. (1982) "Notes on patriarchy, professionalization and the semiprofessions", Sociology, Vol. 16 No. 2, pp. 184-202.

Herring, C. (2009), "Does diversity pay?: Race, gender, and the business case for diversity", American Sociological Review, Vol. 74 No. 2, pp. 208-224.

Janssens, M. and Zanoni, P. (2014), “Alternative diversity management: Organizational practices fostering ethnic equality at work", Scandinavian Journal of Management, Vol. 30 No. 3, pp. 317-331.

Jensen, H.S and Frøling, P. (2006), "Lotterne banede vejen for kvinder i forsvaret", KVINFOs webmagasin, May 4th 2006.

Klarsfeld, A., Ng, E., and Tatli, A. (2012), "Social regulation and diversity management: A comparative study of France, Canada and the UK", European Journal of Industrial Relations, Vol. 18 No. 4, pp. 309-327. 
Kossek, E.E., Lobel, S.A. and Brown, J. (2006), WHuman resource strategies to manage workforce diversity. In Konrad, A. M., Prasad, P., and Pringle, J. (Eds.) (2006) Handbook of workplace diversity. Sage.

Kronsell, A. (2012), Gender, Sex, and the Postnational Defense. Militarism and Peacekeeping, Oxford University Press.

Larsen, J. (1994), "Kvinder i militærhistorien", Forum - tidsskrift for køn og kultur, October 1994.

Lyngsie, J. and Foss, N.J. (2016), "The more, the merrier? Women in topmanagement teams and entrepreneurship in established firms", Strategic Management Journal, DOI: 10.1002/smj.2510

Mackenzie, M. (2015), Beyond the Band of Brothers. The US Military and the Myth That Women Can't Fight, Cambridge University Press.

Magala, S. and Flory, M. (2012), "The rhetoric and narratives in management research", Journal of Organizational Change Management, Vol. 25 No. 2, pp. 201203.

Maninger, S. (2008), "Women in Combat: Reconsidering the Case Against the Deployment of Women in Combat-Support and Combat Units", in H. Carreiras and G. Kümmel (Eds.) Women in the Military and in Armed Conflict, VS Verlag für Sozialwissenschaften.

Mouton, N., Just, S.N and Gabrielsen, J. (2012), “Creating organizational cultures”, Journal of Organizational Change Management, Vol. 25 No. 2, pp. 315-331.

Muhr, S.L. (2011), "Caught in the gendered machine: On the masculine and feminine in cyborg leadership", Gender, Work and Organization, Vol. 18 No. 3, pp. 337-357.

Muhr, S. L., and Salem, A. (2013), “Specters of colonialism-illusionary equality and the forgetting of history in a Swedish organization", Management \& Organizational History, Vol. 8 No. 1, pp. 62-76.

Muhr, S.L. and Sullivan, K. (2013), “'None so queer as folk': Gendered expectations and transgressive bodies in leadership", Leadership, Vol. 9 No. 3, pp. 416-435. 
Muttarak, R., Hamill, H., Heath, A., and McCrudden, C. (2013), “Does Affirmative Action Work? Evidence from the Operation of Fair Employment Legislation in Northern Ireland", Sociology, Vol. 47 No. 3, pp. 560-579.

Oswick, C., and Noon, M. (2014), “Discourses of diversity, equality and inclusion: trenchant formulations or transient fashions?" British Journal of Management, Vol. 25 No. 1, pp. 23-39.

Qin, J., Smyrnios, K. X., and Deng, L. (2014), “An extended intervening process model: Diversity, group processes, and performance", Human Resource Development Review, Vol. 13 No. 2, pp. 133-157.

Parada, M.J. and Viladás, H. (2010), "Narratives: A powerful device for values transmission in family businesses", Journal of Organizational Change Management, Vol. 23 No. 2, pp. 166-172.

Sløk-Andersen, B. (2014), Kvindernes trinvise adgang til det danske forsvar, Forsvarsakademiets Forlag, Forsvaret.

Spradley, J.P. (1980), Participant Observation, Wadsworth Cengage Learning. Sullivan, K.R. (2012), "Producing professionals: Exploring gendered and embodied responses to practicing on the margins", Ephemera: Theory and Politics in Organization, Vol. 12 No. 3, pp. 273-293.

Sundevall, Fia (2011), Det sista manliga yrkesmonopolet: genus och militärt arbete i Sverige 1865 - 1989, Makadam.

Søndergaard, D.M. (2000), "Destabiliserende diskursanalyse. Veje ind i poststrukturalistisk inspireret empirisk forskning", in H. Haavind (Ed.), Kön och tolkning. Metodiska möjligheter i kvalitativ forskning, Natur och Kultur.

Totland, O.M. (2009), Det operative fellesskapet. En sosialantropologisk studie av kropp, kjønn og identitet blant norske soldater i Telemark Bataljon, MA thesis, University of Oslo.

Tracy, S.J. and Rivera, K.D. (2010), “Endorsing equity and applauding stay-at-home moms: how male voices on work-life reveal aversive sexism and flickers of transformation", Management Communication Quarterly, Vol. 24 No.1, pp. 3-43. 
Zanoni, P. and Janssens, M. (2004), “Deconstructing difference: The rhetoric of human resource managers diversity discourses". Organization Studies, Vol. 25 No. 1 , pp. $55-74$.

Zanoni, P. and Janssens, M. (2015), "The power of diversity discourses at work: On the interlocking nature of diversities and occupations, Organization Studies, Vol. 36 No. 11, pp. 1463-1483.

Øhrstrøm, B. et al. (2003), Undersøgelse af forekomst og oplevelse af kønskrænkende adfærd $i$ Forsvaret. Hovedresultater, Forsvarsakademiet, Forsvaret.

Žižek, S. (1989), The Sublime Object of Ideology, Verso, London

\section{Acknowledgements}

The document analysis, as well as six of the interviews, have been carried out on behalf of The Royal Danish Defence College. 